\title{
Analysis of Mobile Telecommunication Development and Operational Practices Vis-à-Vis 4G Wireless Technology
}

\author{
Chigozirim Ajaegbu ${ }^{1}$; Oludele Awodele ${ }^{1}$; Ernest E. Onuiri ${ }^{1}$ \& Edward C. \\ Onyenweaku ${ }^{2}$ \\ ${ }^{I}$ Department of Computer Science, Babcock University, Ilishan-Remo, Ogun State; Nigeria. \\ ${ }^{2}$ New Horizons Systems Solutions, Nigeria
}

\begin{abstract}
G is a brand name for the Fourth Generation of the cellular wireless standards. Over the years, Nigerian telecommunication firms have been in operation with predecessor generation standards (such as $2 \mathrm{G}$ and $3 \mathrm{G}$ ). The design principle of each of these cellular wireless standards follow the same principle, where the information to be transmitted will pass from transmitter through a channel to the receiver at a frequency within the allowable band. For a long distance transmission to take place, information to be transmitted need to be modulated with high frequency also known as carrier frequency. This implies that for any licensed telecom firm in Nigeria, a carrier frequency slot from the regulatory body must be allotted. This research work aims to study the practice of telecommunications in Nigeria vis-à-vis the latest $4 \mathrm{G}$ technology around the world; identify the existing technologies in Nigeria; identify the limitations of Telecommunication Service Providers (TSPs) in Nigeria that may be responsible for delay (if any) in migration to 4G technology. The research methodology that was adopted in this research is the survey, interview, questionnaires and the use of statistical analysis tool (SPSS).
\end{abstract}

Keywords: Telecommunication, Communication, Fourth Generation (4G), Transmission

\section{Introduction}

Telecommunication is a combination of two words "Tele" (from Greek) meaning Far and "Communication" meaning interaction between two or more entities. Centuries ago, communication in Nigeria was only by means of postal services and had some limitations in terms of delay, means of delivery, high cost of delivery etc. As technology advances, such limitations were controlled thus making life easier in terms of meeting the communication needs of Nigerians.

Generally, telecommunication appears to be the backbone to every country's economy and therefore plays a vital role. It is a sector that every other sector such as Agriculture, Banking, Education, Oil etc. in any country depends/revolves within for its survival as depicted in Fig 1. Telecommunication sector is an allinclusive and indispensable sector of any nation economy.

Research has shown that advances in the world's telecommunication generation technology occurs every ten years and follows the same principle of design. Nigeria's mobile market is developing faster than any other sector with the development of Wireless communication and the government decision to award mobile licences to several international Providers.

For effective, efficient and meaningful communication within any country and across the globe, there is a need to regulate the practice of telecommunication locally and internationally to which every licensed telecommunication provider must adhere.

The Nigeria telecommunication sector was grossly under development before been reformed by the military regime under the auspices of Nigeria Communications Commission (NCC). Before the establishment of NCC, the cable and wireless Act of 1962 established the Federal Ministry of Communications as the regulatory body for telecommunication in Nigeria. This ministry regulated Nigeria telecommunication industries until 1993 when NCC was institutionalized by a degree of $24^{\text {th }}$ November 1992 which empowered it to regulate the telecommunication sectors of Nigeria economy. 


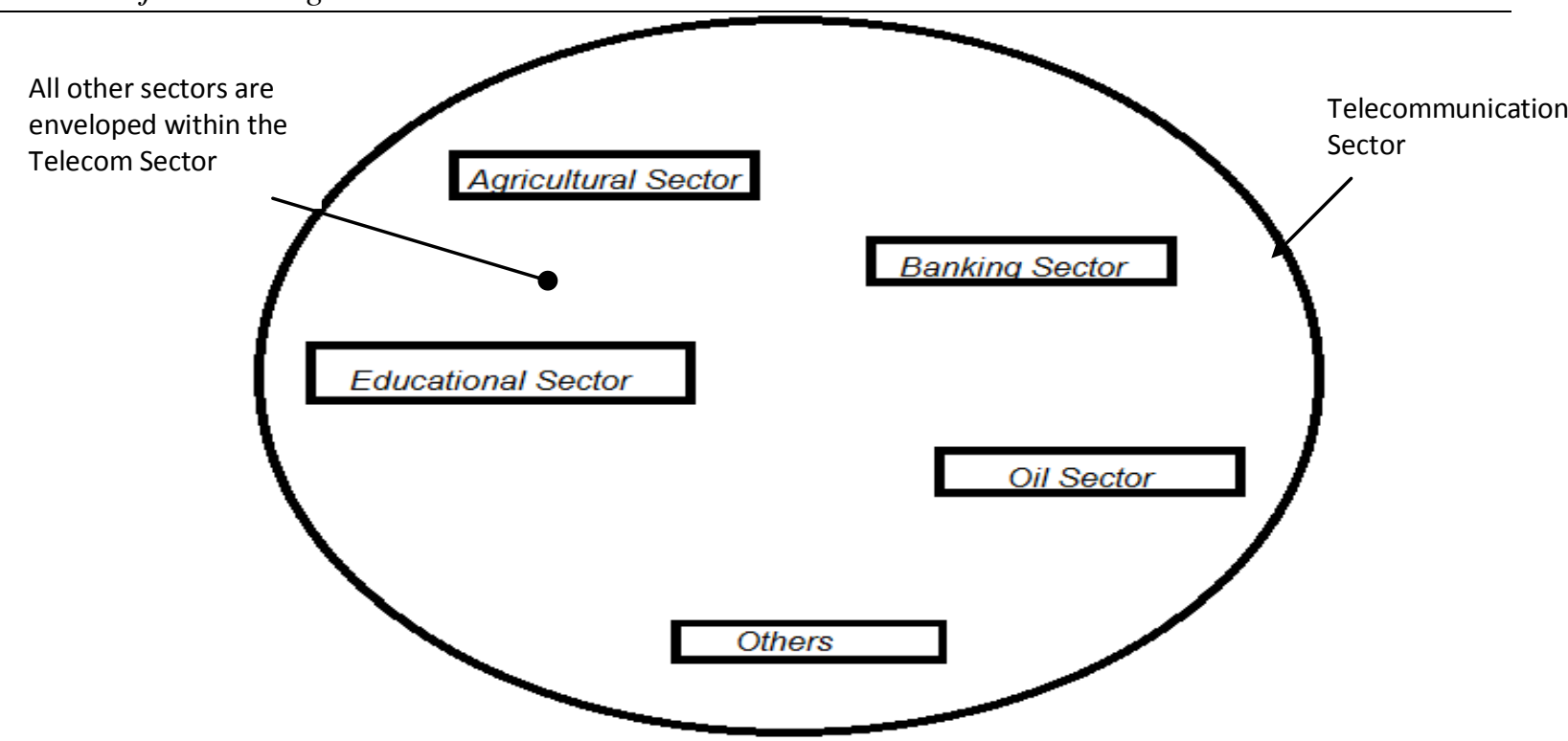

Figure 1: Illustration showing the dependency of other sectors on the Telecom sector

From 1993 till date, NCC has given out licences to a number of mobile telecommunication firms operating as Digital Mobile Services (DMS), Unified Access Services (UAS), and National Carrier Services (NCS). Some of the major licensed telecommunication firms are presented in Table 1.

\begin{tabular}{|c|l|l|l|}
\hline \hline \multicolumn{4}{|c|}{ Table 1: Some major telecom firms licensed in Nigeria [www.ncc.gov.ng] } \\
\hline \hline S/N & NAME & OPERATIVE DATE & EXPIRING DATE \\
\hline 1 & MTN Communication Nigeria Ltd & $\begin{array}{l}9^{\text {th }} \text { February,2001(DMS) and } 1^{\text {st }} \\
\text { Sept. 2006 }\end{array}$ & $\begin{array}{l}8^{\text {th }} \text { Febuary,2016 and } \\
31^{\text {st }} \text { August, 2016 }\end{array}$ \\
\hline 2 & $\begin{array}{l}\text { GLO Mobile Limited (formally } \\
\text { Globacom Ltd) }\end{array}$ & $\begin{array}{l}1^{\text {st }} \text { September, 2002 (DMS and } \\
\text { NCS) }\end{array}$ & $\begin{array}{l}31^{\text {st }} \text { August, 2017 and } \\
31^{\text {st }} \text { August, 2022 }\end{array}$ \\
\hline 3 & Celtel Nigeria Ltd (currently Airtel) & $\begin{array}{l}9^{\text {th }} \text { February, 2001(DMS) and } 1^{\text {st }} \\
\text { December, 2006 }\end{array}$ & $\begin{array}{l}8^{\text {th }} \text { February,2016 and } \\
30^{\text {th }} \text { November, 2016 }\end{array}$ \\
\hline 4 & Starcomms Limited & $1^{\text {st }}$ August, 2006 (UAS) & $31^{\text {st } J u l y, ~ 2016 ~}$ \\
\hline 5 & Multi-links Telecommunication Ltd & $1^{\text {st }}$ November, 2006 (UAS) & $31^{\text {st }}$ October, 2016 \\
\hline 6 & Etisalat Nigeria & January, 2007 (UAS) & \\
\hline 7 & Mobitel Nigeria & May, 2009 & \\
\hline \hline
\end{tabular}

This study focuses on the major licensed telecommunication players in Nigeria in order to measure the rate of mobile telecommunication development in our country.

The adopted methodology that was used in this project are survey, interview, questionnaires which are consequently subjected to statistical analysis using SPSS as a tool. In view of the foregoing, careful survey of the development of mobile telecommunication in Nigeria took a look at seven licensed telecommunications firms in the area of transmission (this comprises of four mobile operators, two fixed wireless operators and one broadband operator).

\subsubsection{Pre Independence Era}

\section{Review of Some Related Works}

The first telecommunication development started in 1886, by the colonial administration with the aim of achieving administrative functions and not to improve on the socio-economic system of the country through the establishment of a cable connection between Lagos and the colonial office in London [Arzika, OFR, 2000]. In the year 1893, Lagos as the capital was provided with telephone services especially government offices and later extended to Ilorin and Jebba. Subsequenty, innovative improvements in the sector began to emerge as an important element in the national telecommunications network. 
IOSR Journal of Electronics and Communication Engineering (IOSRJECE)

ISSN : 2278-2834 Volume 1, Issue 4 (May-June 2012), PP 01-16

www.iosrjournals.org

1923 marked the first commercial telephone trunk established between Itu and Calabar. Between 1946 and 1952, a three-carrier line channel system was commissioned between Lagos and Ibadan and was later extended to Oshogbo, Kaduna, Kano, Benin, and Enugu thereby establishing a collaborative connection between London, Lagos and the commercial centres in the country.

During the pre-independence era, the transmission media that was widely deployed was the unshielded twisted pair (UTP) cable. This advanced through rural carrier systems on high gauge lines to a twelve channel carrier capacity of line carrier systems. In 1955, a small-to-medium carrier system was introduced in order to employ VHF and UHF radio systems. The major and maiden attempt that brought about the development of telecommunication in Nigeria took place between 1955 to 1962. This planning came to provide an expansion of trunk using VHF Multichannel radio system as a nationwide carrier and a short microwave link established between Lagos and Ibadan.

A parallel development was also observed from the telegraph services through delivering of telegraph by way of manual coordinate pegboard switching to the use of Morse code for telex switching. A manual telex exchange of sixty subscriber lines was in use in Lagos before the year 1961. While all these processes were aimed at improving the internal telephone services in Nigeria, the external services during this period were managed and controlled by the Cable and wireless company (a colonial private company) of United Kingdom [Attah, 1998].

\subsubsection{Post-Independence Era}

The attainment of independence in 1960 brought more light to Nigeria as a nation in the development of telecommunication. Telecommunication development plans were featured in each of the five years project plans mapped out during this period.

The primary focus of attainment during this period was the expansion of the network in order to be able to meet the commercial and industrial demands. Its major objectives were:

- Installation of additional 60,000 telephones lines.

- Expansion of trunk dialling facilities in order to link up the major urban cities.

- Establishment of Nigeria External Telecommunications (NET) Limited.

The accomplishment of this task experienced a bottleneck and only (about) 26,000 telephone lines emerged. However, a major achievement which was the installation of microwave radio systems to link the cities of Lagos, Ibadan, Port Harcourt and Benin were accomplished.

The bottleneck opposed to this task emanated as a result of the apparent lack of sufficient funds and partly due to the unrest caused by the Nigeria civil war which lasted between 1967 and 1970. Also the establishment of NET as a limited liability started during this period as well but was not fully operational.

\subsubsection{Cellular Telephony}

The advent of cellular telephony in Nigeria started in 1992 with the introduction of Mobile Telecommunication Service (MTS). It was collaboration between NITEL and Digital telecommunication of Atlanta. MTS became the subscriber's favourite and had a wide monopoly over cellular services in the year 1994. The little improvement that was witnessed from 1994 to 1999 was not enough to meet the minimum continental and global standards. Though the advent of the MTS added more life to the telecommunication sector but still did not reduce the woes of the telephone network in Nigeria.

This challenge continued until the country's Global System for Mobile communication (GSM) revolution began in August, 2001. This revolution helped in changing the face of Information and Communication Technology in Nigeria and also one of the explosive developments the telecommunication industry has ever witnessed. Since the advent of GSM, mobile telephony has become the most popular means of voice communication in Nigeria and has recorded a drastic improvement that the country has been described as "one of the fastest growing GSM markets in the World" [Wojuade, 2006].

This development has indeed been explosive according to statistics from the NCC, compared with about 450,000 working line from NITEL in 2001 where GSM recorded over seven million subscribers as at August 2004. The major operators then were MTN, ECONET (now Airtel), Mobile Telecommunication Limited (mobile subsidiary of the national carrier, NITEL) and Globacom [Ajibose, 2006]. In the year 2001, all the www.iosrjournals.org 
IOSR Journal of Electronics and Communication Engineering (IOSRJECE)

ISSN : 2278-2834 Volume 1, Issue 4 (May-June 2012), PP 01-16

www.iosrjournals.org

major telecommunication players that had emerged, started with the world's $2 \mathrm{G}$ technology (i.e. Digitized voice communication with SMS text) using Global System for Mobile Communication standard and Code Division Multiple Access technology. Also, in a bid to further open up the telecommunication sector in Nigeria, the NCC in 2006 introduced the unified licence regime which allows operators to offer an array of services ranging from voice, data and internet over a single platform. Between the years 2009 and 2010, most of Nigeria's telecom firms (e.g. MTN and GLO) started migrating to the 3G technology (comprising of Digitized voice, Text and Video calls). Till date, Nigeria's mobile telecommunication firms are still implementing the services of $2 \mathrm{G}, 3 \mathrm{G}$ and their respective little upgrades (such as 2.5 and $3.5 \mathrm{G}$ ).

From this review, it has been observed that Nigeria has strived relentlessly over the years to illuminate the quality of life of her citizens through the light of telecommunication. However, this desire could have been more appreciating, if proper planning, management and consistency were upheld. It is quite true that the advent of cellular network brought more life into the telecommunication sector, but operators were mainly concerned with the distribution of more lines, thereby giving less attention to the channel capacity and ITU specifications. Consequently, it became impossible to meet up with the minimum continental and global standards.

\section{G Technology}

Over the years, various standards of cellular wireless telecommunication have emerged. $4 \mathrm{G}$ is the Fourth Generation of the cellular wireless standards and is a successor to the second and third generations. In the year 2008, the International Telecommunication Union Radio communication (ITU-R) organization specified the International Mobile Telecommunication Advance (IMT- Advance) requirement for the $4 \mathrm{G}$ standards. This entails that any $4 \mathrm{G}$ system should be able to operate with a peak data rate of $100 \mathrm{Mbit} / \mathrm{s}$ for high mobility communication (such as cars or trains) and $1 \mathrm{Gbit} / \mathrm{s}$ for low mobility communication (such as stationary users). The ITU organization does not clearly specified the minimum data rate for a $4 \mathrm{G}$ system, in other words, any rate that will be able to meet customers' expectations of broadband data can be employed.

The name 4G was initially used by telecommunication industries as a whole to address cellular technologies with higher capability of wide channel Orthogonal Frequency Division Multiple Access and Single Carrier-Frequency Division Multiple Access technologies, Multiple -In- Multiple - Out technology and an all based Internet Protocol architecture.

Every $4 \mathrm{G}$ system should be able to offer a comprehensive solution/security to computer wireless modem, smart phones and other mobile devices. Also facilities such as IP-telephony, Ultra-mobile broadband Internet access, streamed multimedia may be provided to users.

\subsection{International Telephone Union Requirement/Specifications For 4G Wireless Standards}

Before the IMT-Advance specification was used for $4 \mathrm{G}$ systems, various literatures had looked at the $4 \mathrm{G}$ objectives as improvement on the existing $3 \mathrm{G}$ applications, and may also allow roaming to wireless local area networks with due communication with digital video broadcasting services.

The IMT-Advanced requirements were used by the ITU-R to define the standard for $4 \mathrm{G}$. These requirements are as follows:

(i) All Networks connected to $4 \mathrm{G}$ systems must transmit packets base on IP

(ii) $4 \mathrm{G}$ systems must have a data rate ranging from $100 \mathrm{Mbps}$ for mobile users to $1 \mathrm{Gbits} / \mathrm{s}$ stationary users.

(iii) 4G systems should be designed in such a way that it will allow network users to share network resources simultaneously.

(iv) Flexible bandwidth ranging from 5 to $20 \mathrm{MHz}$ and sometimes up to $40 \mathrm{MHz}$ should be one of its attributes.

(v) Connection spectral efficiency of 15bit/s in the downlink and 6.75bit/s in the uplink should also be one of its attributes.

(vi) Uninterrupted handovers across dissimilar parts should be possible with 4G systems.

(vii) 4G systems should be forward compatible in support of multimedia packets for upcoming generations.

(viii) $4 \mathrm{G}$ systems should be able to offer system spectral efficiency of up to $3 \mathrm{bit} / \mathrm{s}$ cell in the downlink and $2.25 \mathrm{bit} / \mathrm{s}$ cell for indoor usage.

(ix) 4G systems should be able to operate within the frequency range of 2 to $8 \mathrm{GHz}$. (http://www.dailywireless.org/2000/10/21/itu-the-official-4g-standard-approved/) 
IOSR Journal of Electronics and Communication Engineering (IOSRJECE)

ISSN : 2278-2834 Volume 1, Issue 4 (May-June 2012), PP 01-16

www.iosrjournals.org

3.1.1 802.16m standardized by the IEEE (WiMax 2): This is a technology emerging from the umbrella of the IEEE 802.X standards as shown in Figure 2.
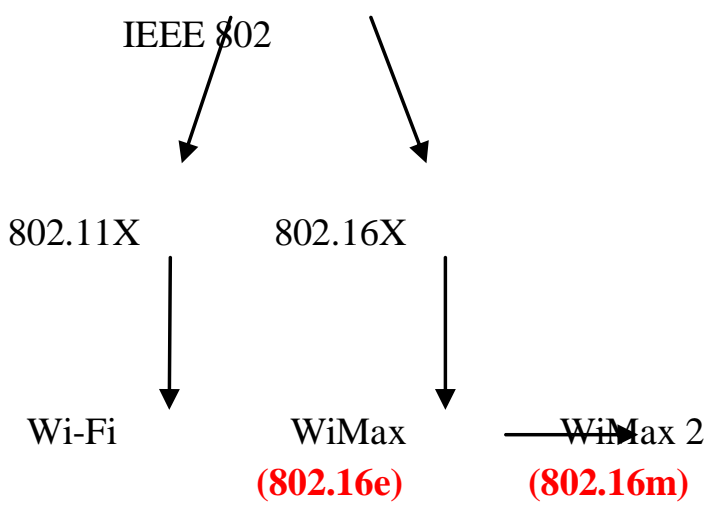

Figure 2: The IEEE 802.X family

It was designed to offer virtually all the basic requirements expected from the $4 \mathrm{G}$ technology. It is backward compatibility with IEEE 802.16e (WiMax). The goal of this WiMax 2 is to offer a downlink speed of more than 100Mbps to users as against the maximum downlink speed of WiMax. The ability of WiMax 2 to offer this high speed for internet connectivity (broadband) is as a result of its smart antenna (a digital wireless communication antenna system that takes advantage of the diversity effect at the transmitter or receiver side or both) and its multichannel approach [Shakouri, 2011].

Shakouri (2011), further said that while the WiMax 2 offers more broadband speed than WiMax, it will not propagate farther than thirty-one square miles $\left(31 \mathrm{mi}^{2}\right.$ or $\left.80,289,631.420416 \mathrm{~m}^{2}\right)$ per access point as being covered by the IEEE 802.16e (WiMax).

3.1.2 LTE Advance standardized by the 3GPP: LTE Advance is an evolved version of LTE (see Figure 3) and also a project name for 4G LTE technology being developed by the 3GPP in order to meet up or exceed the $4 \mathrm{G}$ specification as labeled by the ITU for a true fourth generation radio standard. The advantage of LTE Advance is that it is backward compatible to LTE meaning that LTE devices can work on LTE Advance system and LTE Advance devices can also work with LTE systems.

LTE Advanced design specification as indicated in the 3GPP Release 10 is to offer downlink peak rate of $1000 \mathrm{Mbps}$ for low mobility and $100 \mathrm{Mbps}$ for high mobility. It will be designed in such a way that it will offer all IP high speed for internet connectivity (forty-times faster than $3 \mathrm{G}$ commercial network), low latency and high quality spectrum efficiency in mobile network.

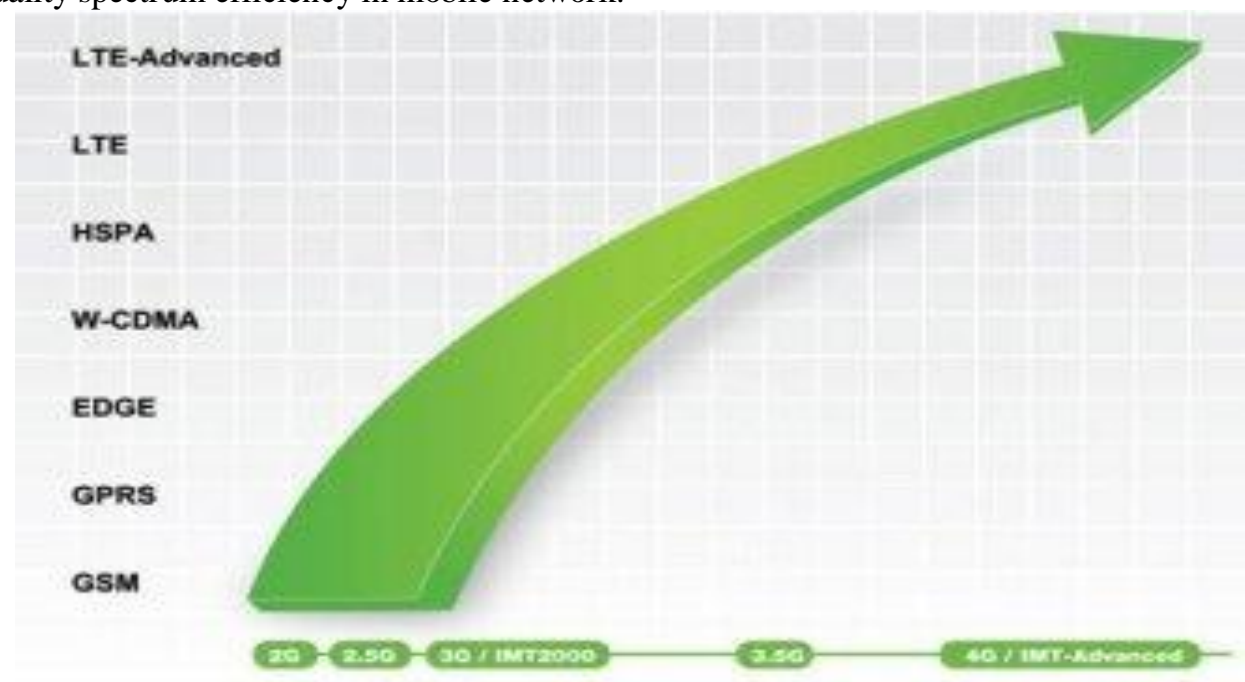

Figure 3: 3GPP standardization family

www.iosrjournals.org 
IOSR Journal of Electronics and Communication Engineering (IOSRJECE)

ISSN : 2278-2834 Volume 1, Issue 4 (May-June 2012), PP 01-16

www.iosrjournals.org

(Source: http://suatmimurnani.wordpress.com/2010/06/30/migrasi-teknologi-gsm-menuju-lte/)

The present existing WiMax and LTE are being used as test birds for the upcoming WiMax2 and LTE Advance, which is being designed to meet up with the $4 \mathrm{G}$ standard as defined by the ITU- R organization and will be considered permanent. Table 2 and 3 show some of the trailing features of these technologies.

\begin{tabular}{|c|c|c|}
\hline \multicolumn{3}{|c|}{ Table 2: Comparative table of WiMax and WiMax 2} \\
\hline FEATURES & WiMax & WiMax 2 \\
\hline Bandwidth range & $1.25 \mathrm{MHz}$ to $20 \mathrm{MHz}$ & $5 \mathrm{MHz}$ to $40 \mathrm{MHz}$ \\
\hline Downlink Speed & Can offer up to 70Mbps & 100Mbps and above \\
\hline Spectrum Range & $2.3 \mathrm{GHz}$ to $3.5 \mathrm{GHz}$ & Below $6 \mathrm{GHz}$ \\
\hline Latency & Low & Lower \\
\hline Range of Coverage & $31 \mathrm{mi}^{2}$ & $\begin{array}{l}\text { Is assumed not to propagate } \\
\text { higher. }\end{array}$ \\
\hline MIMO antenna & $2 \times 2$ MIMO & $4 \times 2$ MIMO \\
\hline Usage & In use & Not yet in use \\
\hline \multicolumn{3}{|c|}{ Table 3: Comparative table of LTE and LTE advance } \\
\hline FEATURES & LTE & LTE Advance \\
\hline Data Rate & 326Mbps & 1200Mbps \\
\hline Compatibility & $\begin{array}{l}\text { Not backward compatible with any } \\
\text { 3G network rather only forward } \\
\text { compatible with LTE Advanced }\end{array}$ & Backward compatible with LTE \\
\hline Spectrum Range & $20 \mathrm{MHz}$ & $40-100 \mathrm{MHz}$ \\
\hline MIMO Technology & $2 \times 2-4 \times 4$ MIMO & $4 \times 4$ MIMO \\
\hline Scalable Carrier Bandwidths & $1.4-20 \mathrm{MHz}$ & $20-100 \mathrm{MHz}$ \\
\hline Latency & Low & Lower \\
\hline Usage & Not common & Not in use \\
\hline
\end{tabular}

\section{Presentation of Data}

This chapter presents the responses got from the interview/questionnaires that were disseminated during the course of the research using frequency distribution table. The responses to each of the variables are measured with a bar chart diagram where each level of bar chart represents the number of respondents to each of the questions.

\subsection{Data Analysis and Interpretation}

Is your company a cellular Network Operator?

\begin{tabular}{|cc|c|c|c|}
\hline & & & & \\
& & Frequency & Percent & Valid Percent \\
\hline Valid & Yes & 9 & 75.0 & 75.0 \\
& No & 2 & 16.7 & 16.7 \\
& Broadband & 1 & 8.3 & 8.3 \\
& Total & 12 & 100.0 & 100.0 \\
& & & & \\
\hline
\end{tabular}


IOSR Journal of Electronics and Communication Engineering (IOSRJECE)

ISSN : 2278-2834 Volume 1, Issue 4 (May-June 2012), PP 01-16

www.iosrjournals.org

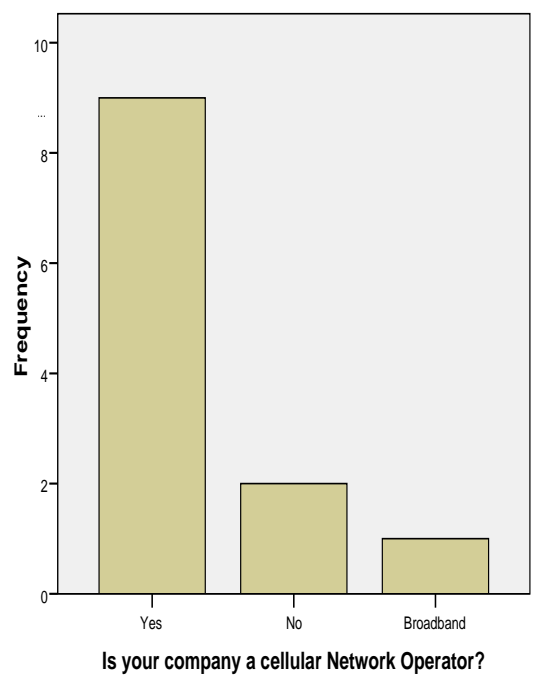

From this chart, it shows that Nigeria has greater percentage of licensed Cellular Network operators than Fixed

Wireless Operators (Broadband Service).

If yes, is your Network Unified i.e. does your network carry data, voice and video?

\begin{tabular}{|cc|c|c|c|}
\hline & & & & \\
& & Frequency & Percent & Valid Percent \\
\hline Valid $\quad$ Yes & 11 & 91.7 & 100.0 \\
Missing System & 1 & 8.3 & \\
\multicolumn{2}{|c|}{ Total } & 12 & 100.0 & \\
\hline
\end{tabular}

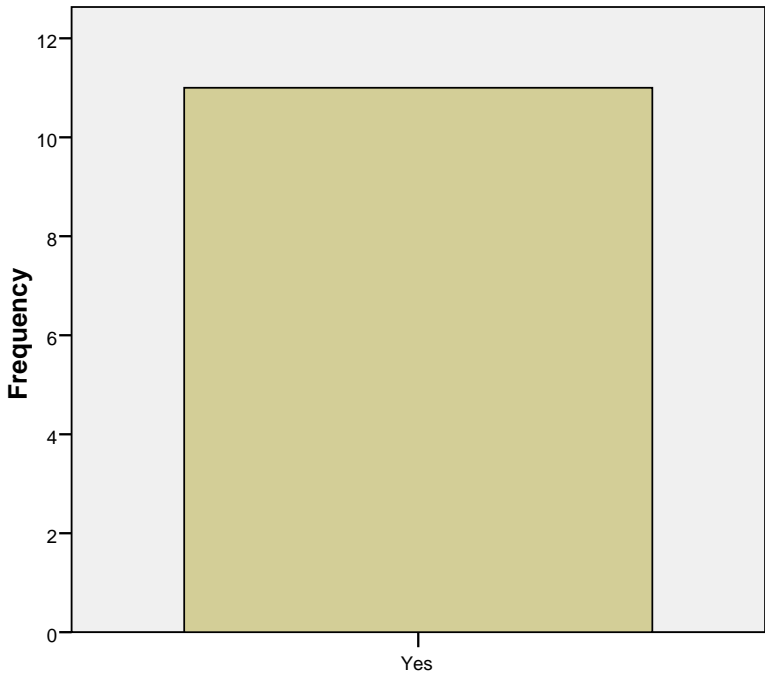

If yes, is your Network Unified i.e. does your network carry data, voice and video?

This shows that Nigeria has completely advanced from the analogue system of communication been regarded as the $1 \mathrm{G}$ technology (voice only) to higher generation technology, that can transmit more than one packet.

Which technology are you using to drive your cellular Network?

www.iosrjournals.org 
IOSR Journal of Electronics and Communication Engineering (IOSRJECE)

ISSN : 2278-2834 Volume 1, Issue 4 (May-June 2012), PP 01-16

www.iosrjournals.org

\begin{tabular}{|cc|c|c|c|}
\hline & & & & \\
& & Frequency & Percent & Valid Percent \\
\hline Valid & others & 3 & 25.0 & 25.0 \\
& WiMax & 1 & 8.3 & 8.3 \\
& GSM & 6 & 50.0 & 50.0 \\
& GSM \& & 2 & 16.7 & 16.7 \\
WiMax & 12 & 100.0 & 100.0 \\
\hline & Total & 12 &
\end{tabular}

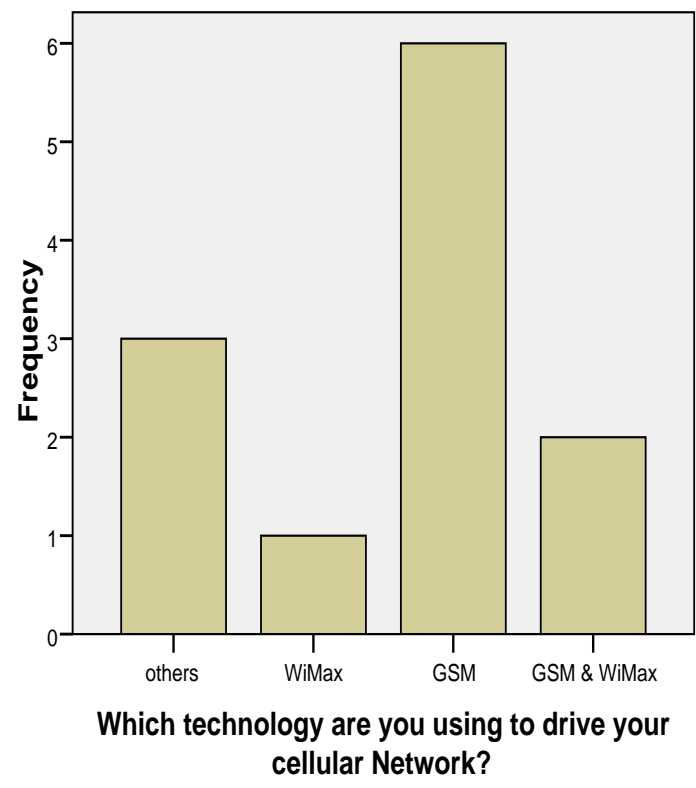

This shows clearly that greater percentage of Nigerian licensed Telecommunication firms, are still using GSM technology in driving their Cellular Network. GSM technology is a technology built with the capacity to drive the $2 \mathrm{G}$ technology and can only transmit voice and data whereas some telecommunication firms are embarking on the use of two different technologies.

What is the frequency range of your operation?

\begin{tabular}{|cc|c|c|c|}
\hline & & & & \\
Valid & others & 6 & 50.0 & 50.0 \\
& $2-8 \mathrm{GHz}$ & 1 & 8.3 & 8.3 \\
& $2-4 \mathrm{GHz}$ & 5 & 41.7 & 41.7 \\
& Total & 12 & 100.0 & 100.0 \\
\hline
\end{tabular}


IOSR Journal of Electronics and Communication Engineering (IOSRJECE)

ISSN : 2278-2834 Volume 1, Issue 4 (May-June 2012), PP 01-16

www.iosrjournals.org

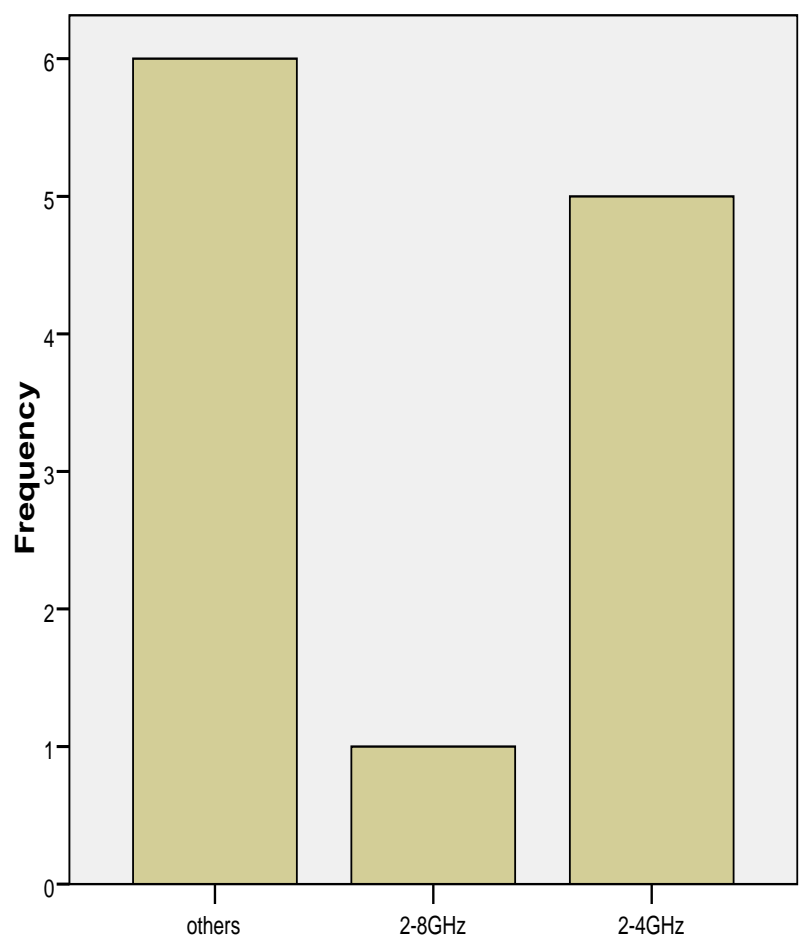

What is the frequency range of your operation?

The frequency range allocation all depends on NCC. Since from the data, frequency ranges of $2-4 \mathrm{GHz}$ and $2-8 \mathrm{GHz}$ was claimed to be issued out by the NCC, they are only used by most of the telecom firms to transmit data over the internet.

What is your bandwidth range?

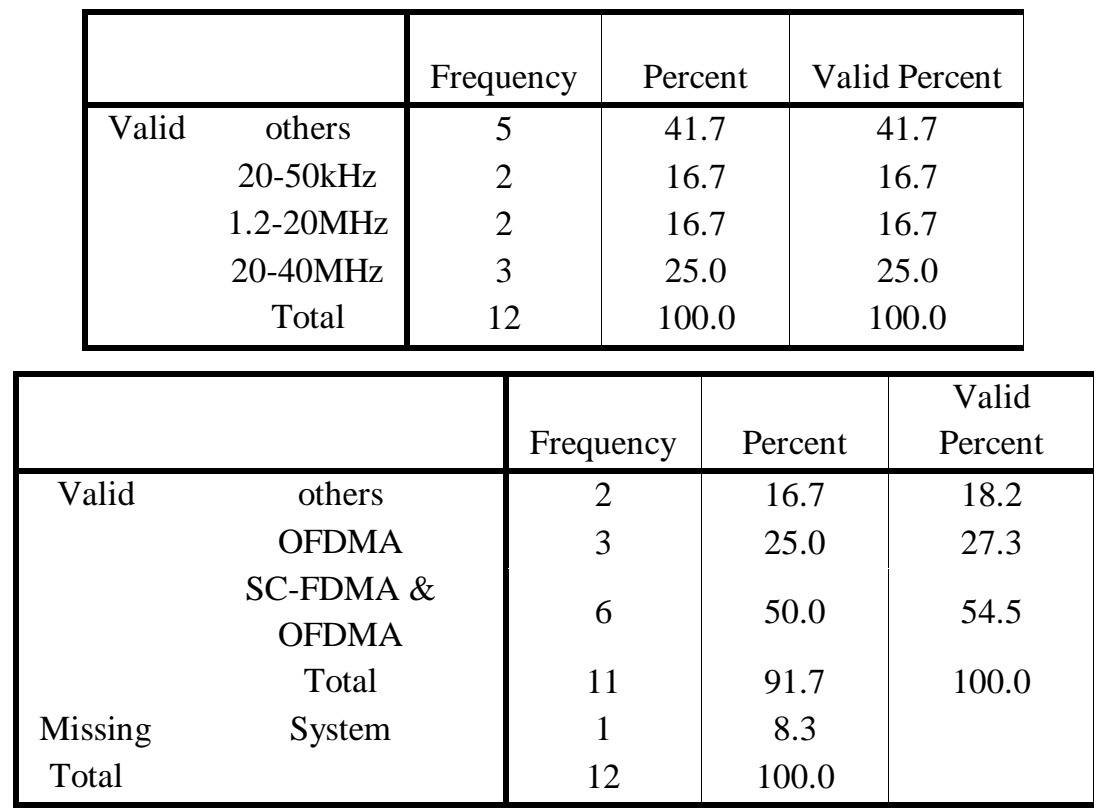


IOSR Journal of Electronics and Communication Engineering (IOSRJECE)

ISSN : 2278-2834 Volume 1, Issue 4 (May-June 2012), PP 01-16

www.iosrjournals.org

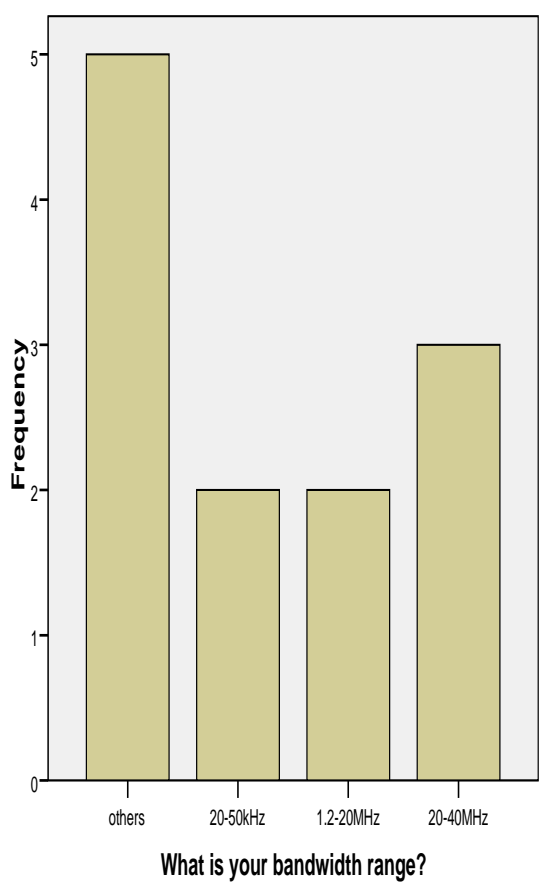

From the data, it shows that bandwidth purchase all depend on the various telecommunication firms.

Which switching technique does your network use?

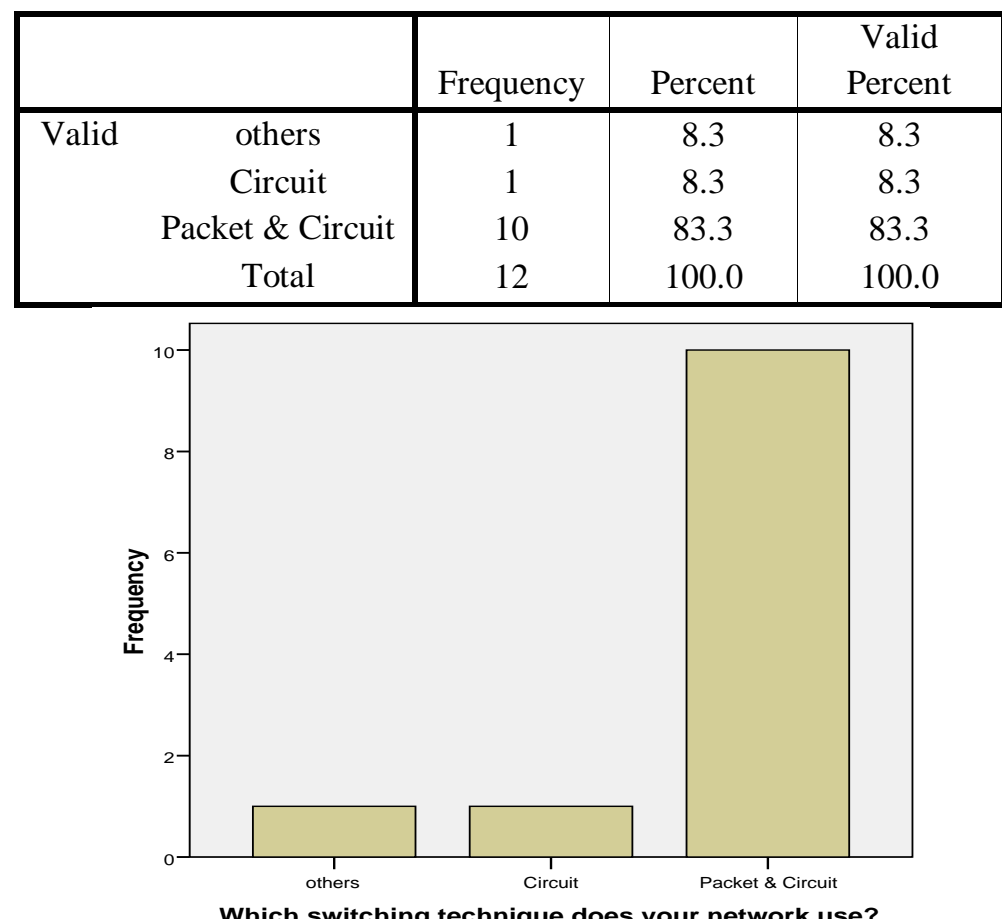

This shows that Nigeria telecommunication firms, both cellular operators and Fixed Wireless operators are still using switching technique meant for $2 \mathrm{G}$ and $3 \mathrm{G}$ technology (i.e. Circuit and Packet \& circuit switching techniques). 
IOSR Journal of Electronics and Communication Engineering (IOSRJECE)

ISSN : 2278-2834 Volume 1, Issue 4 (May-June 2012), PP 01-16

www.iosrjournals.org

Which of the multiplexing techniques is used for your transmission?

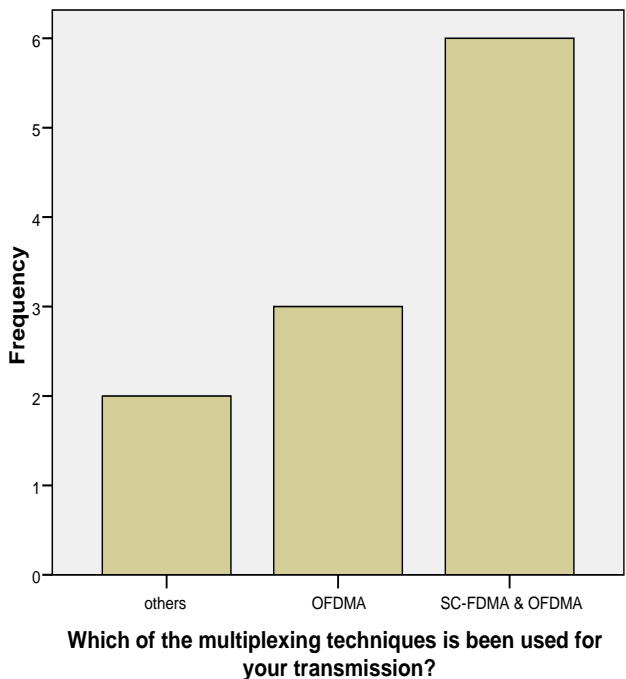

The data also shows that each multiplexing technique all depends on the technology each of the telecom firms are embarking on and the usage.

Which range of connection spectral efficiency does your system offers for Uplink and Downlink respectively?

\begin{tabular}{|cc|c|c|c|}
\hline & & & & \\
& & Frequency & Percent & Valid Percent \\
\hline Valid & others & 7 & 58.3 & 63.6 \\
& 3-6.75bit/s & 2 & 16.7 & 18.2 \\
& 5.5-15bit/s & 2 & 16.7 & 18.2 \\
& Total & 11 & 91.7 & 100.0 \\
Missing System & 1 & 8.3 & \\
\multicolumn{2}{|c|}{ Total } & 12 & 100.0 & \\
\hline \multicolumn{2}{|c|}{}
\end{tabular}

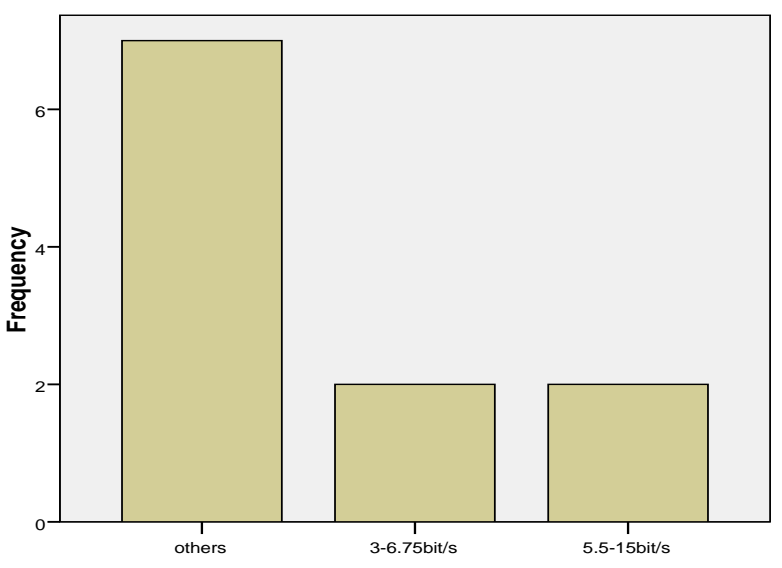

Which range of connection spectral efficiency does you system offers for Uplink and Downlink respectively?

This depends on the technology being embarked by each of the telecommunication firms. It shows that none of the operators are meeting up with the required $4 \mathrm{G}$ standard of connection spectral efficiency 
IOSR Journal of Electronics and Communication Engineering (IOSRJECE)

ISSN : 2278-2834 Volume 1, Issue 4 (May-June 2012), PP 01-16

www.iosrjournals.org

for Uplink and Downlink respectively.

What is your system spectral efficiency cell for indoor usage?

\begin{tabular}{|cc|c|c|c|}
\hline & & & & \\
& & Frequency & Percent & Valid Percent \\
\hline Valid & others & 6 & 50.0 & 54.5 \\
& 3.5bit/s & 5 & 41.7 & 45.5 \\
& Total & 11 & 91.7 & 100.0 \\
Missing System & 1 & 8.3 & \\
\multicolumn{2}{|c|}{ Total } & 12 & 100.0 & \\
\hline
\end{tabular}

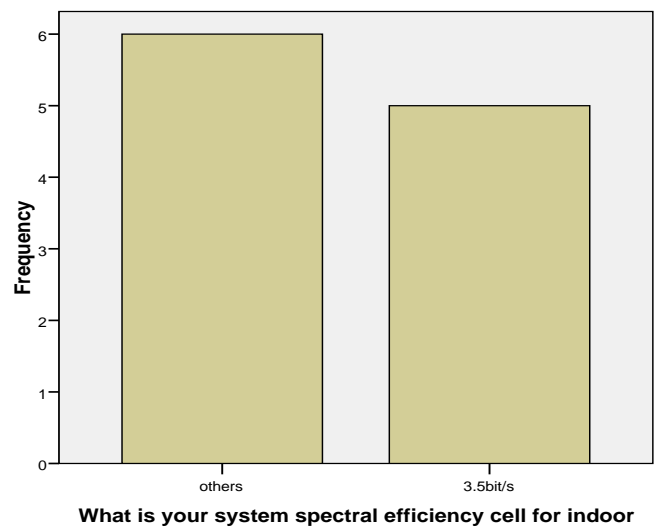

What is your system spectral efficiency cell for indoor

This is dependent upon the technology being used and also depends on the positioning of the router.

Is your technology designed to allow network users share and utilize network resources simultaneously?

\begin{tabular}{|cc|c|c|c|}
\hline & & & & \\
& & Frequency & Percent & Valid Percent \\
\hline Valid & Yes & 10 & 83.3 & 83.3 \\
& Don't know & 2 & 16.7 & 16.7 \\
& Total & 12 & 100.0 & 100.0 \\
\hline
\end{tabular}

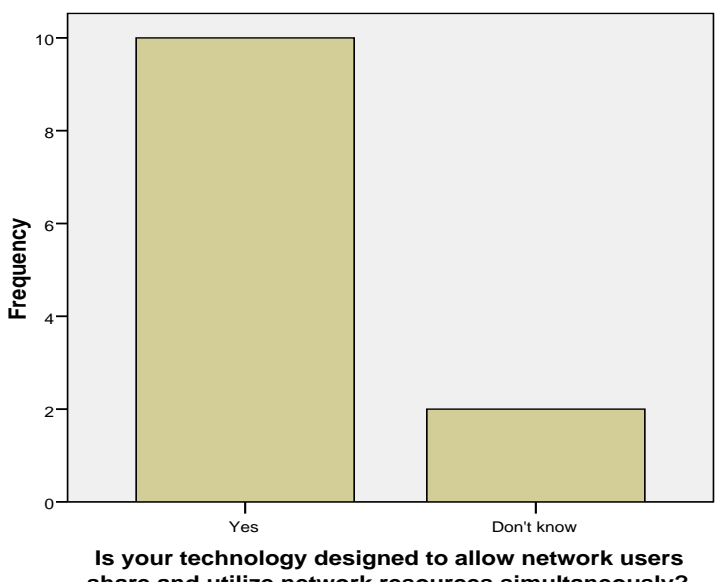

share and utilize network resources simultaneously?

www.iosrjournals.org 
IOSR Journal of Electronics and Communication Engineering (IOSRJECE)

ISSN : 2278-2834 Volume 1, Issue 4 (May-June 2012), PP 01-16

www.iosrjournals.org

The data shows that greater percentage of the different technologies being used in Nigeria, has the capability of allowing users share and utilize resources simultaneously.

Which generation technology does your company use?

\begin{tabular}{|cc|c|c|c|}
\hline & & & & \\
& & Frequency & Percent & Valid Percent \\
\hline Valid & $2.5 \mathrm{G}$ & 1 & 8.3 & 8.3 \\
& $3 \mathrm{G}$ & 6 & 50.0 & 50.0 \\
& $3.5 \mathrm{G}$ & 4 & 33.3 & 33.3 \\
& $4 \mathrm{G}$ & 1 & 8.3 & 8.3 \\
& Total & 12 & 100.0 & 100.0 \\
\hline
\end{tabular}

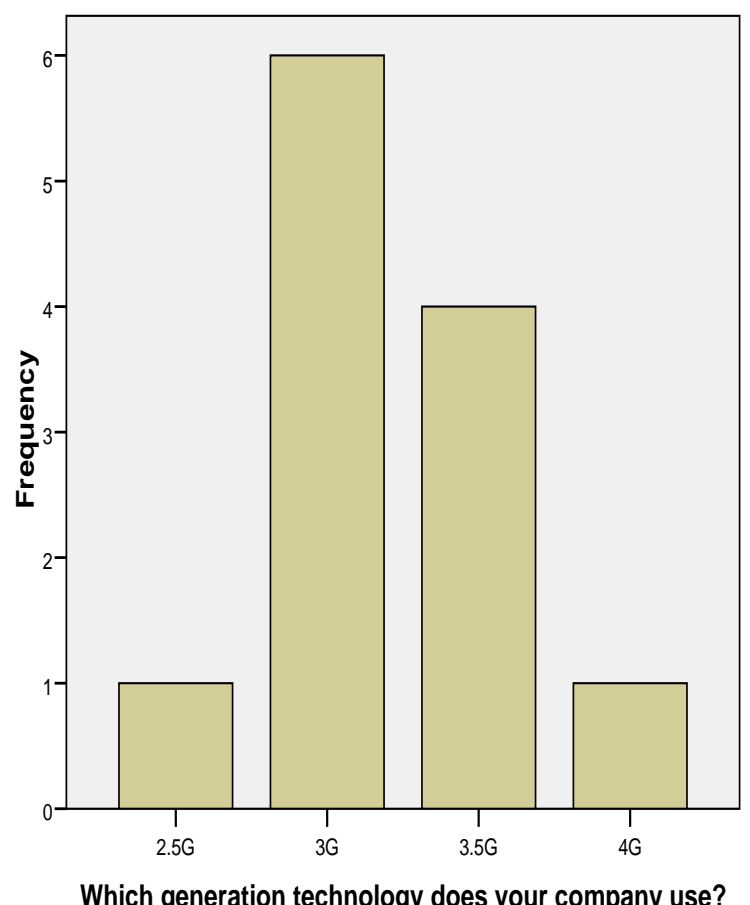

This data shows that greater percentage of Nigeria's telecommunication firms are more on $3 \mathrm{G}$ and $3.5 \mathrm{G}$ technology whereas lower percentage claimed to be on $2.5 \mathrm{G}$ and $4 \mathrm{G}$ technology.

Is your system designed to be forward compatible in supporting future generation multimedia packets technology?

\begin{tabular}{|lc|c|c|c|}
\hline & & & & \\
& Frequency & Percent & Valid Percent \\
\hline Valid & Yes & 12 & 100.0 & 100.0 \\
\hline
\end{tabular}




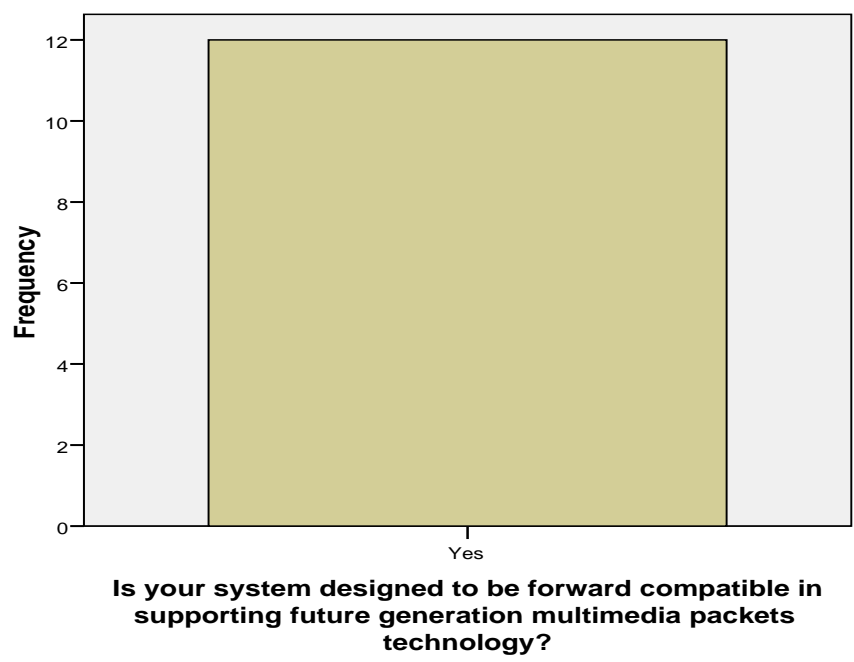

The chart shows that all the technologies in use are meant to be forward compatible in supporting future multimedia packets technology.

\subsection{Research Findings}

In the course of this research, the following observations were made:

- The claims some of our cellular operators are not true and that the cellular technologies in Nigeria are: $2 \mathrm{G}, 2.5 \mathrm{G}, 3 \mathrm{G}$ and $3.5 \mathrm{G}$.

- Our broadband operators are currently using a system that is serving the purpose of a pre-4G technology. Hence, they do not have the full capacity to operate as a $4 \mathrm{G}$ system.

- Some of the telecom firms are using two different technologies for their transmission and this is as a result of the inability of one technology not being able to accommodate the carrying capacity of the firm which it has grown to over the years and the inherent difficulty or inability to migrate from the existing technology to a higher one. This has resulted to some telecom firms having more than one base station in a cell site.

- None of the Nigerian cellular network operators is currently using $4 \mathrm{G}$ for its voice transmission and more bandwidth was purchased for their data transmission over the internet than their voice transmission using cellular phones. This is the reason why voice transmission encounters more congestion as compared to data transmission.

- Some Nigerian broadband operators, operating with technologies not having the full capacity to carry the $4 \mathrm{G}$ network. Such operators can therefore be classified as Pre-4G technology providers in accordance to the global standards.

- $\quad$ Frequency range of $2-4 \mathrm{GHz}$ is being given out by the $\mathrm{NCC}$ whereas $4 \mathrm{G}$ systems are meant to operate within the range of $2-8 \mathrm{GHz}$. This $2-4 \mathrm{GHz}$ is being used by telecom firms operating with $2.5 \mathrm{G}, 3 \mathrm{G}, 3.5 \mathrm{G}$ and Pre-4G technology for their transmission.

\section{Recommendations}

To achieve an appropriate frequency allocation, the NCC has the role of making sure that each frequency band being allotted to any of the licensed telecommunication firm, should fall within the range of ITU specification for the technology in question (e.g. 4G is specified to operate within the frequency range of $2-8$ $\mathrm{GHz}$ ). Telecommunication firms should adhere to the basic principle of communication and also be ready to fully invest in any upgrade rather than operating with two different technologies and clustering cell sites with more than one base station. One tower per base station is enough anti-aesthetic value not to mention an additional one. These towers are also easy targets for terrorist attacks because of their conspicuous identification from the space; too many of them would pose a great danger on the security of the nation. It is 
IOSR Journal of Electronics and Communication Engineering (IOSRJECE)

ISSN : 2278-2834 Volume 1, Issue 4 (May-June 2012), PP 01-16

www.iosrjournals.org

also of importance that they should be ready to invest more on the bandwidth of their voice transmission since majority of the Nigerian telecom subscribers are more interested in the voice transmission of cellular network.

These measures will help in uplifting Nigeria to the height of the world's $4 G$ and thus Nigerian telecommunication firms can comfortably boast of operating with $4 \mathrm{G}$ and any other technology that might come up in the nearest future.

\subsection{Conclusion}

Our lives are shaped by societal and business communities. Communication technology helps to connect and grow these communities, transform lives throughout Africa and the world. Information and Telecommunications have contributed immensely in building strong, long-term relationships with customers and communities in Sub-Saharan and beyond in the recent time. Nigeria, the most populous black nation in the world, has always been a very important gateway to business on the continent of Africa and beyond, with one of the most vibrant and dynamic business communities in emerging markets. Networking and Telecommunication have stood to offer tremendous opportunities for growth in the industry and the Nigerian economy as a whole and will continue to play a major role in the economic revolution in Nigeria and in the entire Africa.

The acquisition of GSM equipment in this country has really promoted technology research in Nigerian universities which has given birth to many innovations that have not only impacted the daily lives of Nigerians but have contributed in no small measure, in alleviating poverty by creating many job opportunities for our youths. In essence, Nigerian government should endeavour to embrace any generational innovation with sanity and proper planning in order to exercise a good and effective telecommunication system.

\subsection{Future Work}

WiMax 2 and LTE advances appear to be the two proposed technologies for operating $4 \mathrm{G}$ technology. A suggested future work will be to carry out a comparative analysis of these two technologies since they are standardized by two different bodies and suggest modification on lapses (if any) in any of the technology.

\section{REFERENCES}

[1] Adegboyega D. (2008). Tell Magazine. Seven Years of Telecoms Revolution-Telecommunication is an Expensive Project. 16-17.

[2] Ademilola B. (2007). Tell Magazine. The Telecoms Revolution-NCC, its Mandate, its Vision. 5.

[3] Ademola O. (2008). Tell Magazine. Seven Years of Telecoms Revolution. 16-17

[4] Ajayi G.O, Salawu R.I, Raji T.I (2011). A century of Telecommunication Development in Nigeria- What next. Oxford Scholarship Online, 163.

[5] Ajibose O. (2006). Performance Evaluation of Fixed Cellular telecommunication Networks using Java. (Unpublished master's thesis). University of Ibadan, Nigeria.

[6] Ajiboye O., Adu O., Wojuade I. (2007). The Impact of GSM on Nigeria Rural Economy:

[7] Implication for an Emerging Communication Industry. Journal of Information Technology Impact, Vol.7 (2), $131-144$.

[8] Akuamoa W. (2007). Telecommunication Development in Africa- Ghana has come a long way. Retrieved on August 21,2011 from http://www.modernghana.com/news/132898/1/telecom-development-in-africaghana-has-come-a-long.html.

[9] Alabi G.A. (1996). "Telecommunications in Nigeria", Retrieved on September 12, 2011. From http://www.africa.upenn.edu/ECA/aisi_inftl.html.

[10] Arzika M.(2000). National Policy on Telecommunications Retrieved on October 21 , 2011 from http://www.researchictafrica.net/countries/nigeria/NationalPolicy on Telecommunication.pdf.

[11] Behrouz A. F. (2006). Data Communication and networking. India: McGraw-Hill Education India Pvt Ltd.

[12] Bernard S. (2003). Digital Communication- Fundamentals and Applications. New Jersey: Library of Congress.

[13] Bruce C. (1975). Communication Systems an Introduction to signals and noise in electrical communication. United States of America: McGraw-Hill.

[14] Carlson, Crilly, Rutledge (2002). Communication Systems- An Introduction to Signals and Noise in Electrical Communication. (4 ${ }^{\text {th }}$ edition). New York: McGraw- Hill.

[15] Edwin W and Deon R .(2004). Telecommunication and Wireless Communication for Bussiness and Industry. ( ${ }^{\mathrm{st}}$ edition). Burlington: IDC technologies.

[16] European Foundation for the Improvement of Living and Working Conditions (2005). The future of telecommunications services: outline of four scenarios. Retrieved on October 29, 2011. from- https://communities.uhi.ac.uk/climatic/files/57/444/ef0567en.pdf

[17] Gordon W. (1994). Mobile Radio Technology. Jordan Hill: British Library.

[18] Jofr J.A. (1999). Telecommunication Development in Bolivia. Retrived on November 14, 2011 
IOSR Journal of Electronics and Communication Engineering (IOSRJECE)

ISSN : 2278-2834 Volume 1, Issue 4 (May-June 2012), PP 01-16

www.iosrjournals.org

[19] fromhttp://webcache.googleusercontent.com/search?q=cache:Y43KYEtVnr4J:Www.connect-

world.com/ cwiml/index.php/magazine/latin-america/item/1987-telecommunications-development-in

bolivia+telecommunication+development+in+bolivia\&cd $=3 \& \mathrm{hl}=\mathrm{en} \& \mathrm{ct}=\mathrm{clnk} \& \mathrm{gl}=\mathrm{ng}$.

[20] Mischa S. (1980). Information Transmission Modulation and Noise. United State of America: McGraw-Hill.

[21] Ndukwe E .(2007). Tell Magazine. Transforming Nigeria's telecoms industry. 6-7.

[22] Nosa I.(2007). Tell Magazine. Origin of Telecommunication Revolution in Nigeria. 5-7

[23] Ohiri K. (1999). Recent Development in Nigerian Telecommunications Law and Policy,

[24] Retrieved on 17/09/2011 from http://www.scribd.com/doc/36166134/Recent-Developments-in-Nigerian.

[25] Onome S. (2002). Tell Magazine. The Telecoms Revolution. 4-5.

[26] Onosode G. (2008). Tell Magazine. Seven Years of Telecoms Revolution. 12-13.

[27] Pyramid Research (2010). The Impact of Mobile Services in Nigeria- How Mobile Technologies are Transforming Economic and $\begin{array}{llllll}\text { Social Activities } & \text { Retrived } & \text { on } & \text { June } & 13, & \text { from }\end{array}$ http://www.pyramidresearch.com/documents/ImpactofMobileServicesInNigeria.pdf.

[28] Salawu, R.I. (1991). "Telecommunications in Focus”, 10th Anniversary Lecture for 2-Way Communications Ltd, Lagos.

[29] Seven years of Telecoms revolution (2008). Tell Magazine. What the future holds for Nigeria, The big bang 7-9 .

[30] Shakouri M.(2011). 8 pieces of cool WiMAX gear Retrived on July 20, 2011 from http://www.wimaxforum.org/news/837.

[31] Sharma S.P. (2003). Basic Radio Technology. New York: McGraw Hill.

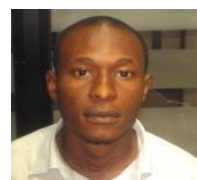

Ajaegbu, Chigozirim is an Assistant Lecturer in the Computer Science Department of Babcock University. He is a graduate of Computer Science (Technology) and also has a Master degree holder in Computer Science, from Babcock University. He is a Cisco Certified Network Associate (CCNA) and a Certified Security+ Professional. He has practically trained with an ISP firm and had also worked in a Broadcasting firm as a System Engineer. His areas of interest include Networking and Telecommunication, Computer Security, Green IT and Cloud Computing.

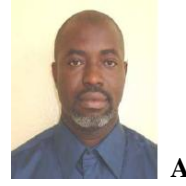
years experience of teaching computer science courses at the university level. He is currently a lecturer in the department of Computer Science, Babcock University, Nigeria. He is a full member of the Nigeria Computer Society (NCS) and the Computer Professional Registration Council of Nigeria. His areas of interest are Artificial Intelligence, Cloud Computing and Computer Architecture. He has published works in several journals of international repute.

[1] Theraja B.L. (2004). Fundamentals of Electrical Engineering and Electronics. New Delhi: S.Chand \& Company Ltd.

[2] Wakefield, McNally, Bowler (2007). Introduction to Mobile Communication Technology-Services, Markets. New York: Auerbach Publications.

[3] Wright, Reynders (2004). Practical Telecommunication and Wireless Communications for Business and Industry. New York: British library.

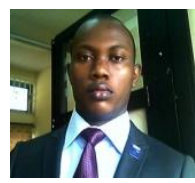

Onuiri, Ernest Enyinnaya is a Graduate Assistant in the Computer Science Department of Babcock University. He is a graduate of Computer Science (Technology) from Babcock University. He is a Cisco Certified Network Professional [CCNP] and a Certified Security+ Professional. He is currently doing his M.Sc. in Computer Information Systems at Babcock University. His areas of interest include networking and security, cloud computing, intelligent computing and bioinformatics.

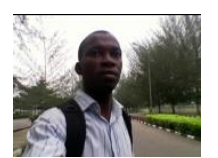

Onyenweaku Edward Chidiebere is a Team Leader, Network and IT projects of New Horizon Systems Solutions. He is a graduate of Computer Science from Babcock University. He has the following certifications in IT: CCSI\#33077 (Cisco Certified Systems Instructor), CCNP (Cisco Certified Network Professional), CEH (Certified Ethical Hacker), CCNA (Cisco Certified Network Associate), CCDA (Cisco certified Design Associate), CompTIA Security+ professional, CCNA Voice. He is currently doing his M.sc in Security Science with ECCouncil, USA. His areas of interest are networking and security 